\title{
Marlowe and Bruno
}

\section{by Nicholas Ranson}

In the Introduction to her 1965 edition of Doctor Faustus, Roma Gill reminds us that the comic pope and anti-pope scene in the B-text are based upon certain elements in history as recorded in Foxe's Actes and Monuments. ${ }^{1}$ I should like to hypothesize about the relationship of the source to the scene.

The relevant lines are 895-1010. ${ }^{2}$ The Pope and Raymond, King of Hungary enter with the chained Saxon Bruno. The Pope ${ }^{3}$ addressed later by Bruno as Adrian uses Bruno as a footstool to ascend his papal throne. Bruno is then taken away by the Lords Cardinal of France and Padua, who are instructed to find out what the Council of Trent has decreed as the punishment for antipopes. Faustus and Mephistopheles shortly after enter in the assumed persons of the two Cardinals (976) and declare:

The Statutes Decretall haue this decreed, He shall be streight condemn'd of heresie And on a pile of Fagots burnt to death. (992-994)

The Pope assigns Bruno to the strongest Tower "of Ponto Angelo" and promises to "determine of his life or death" the next day. Then, in lines 1015-20, we learn that Bruno has been transported "as swift as thought ... to fruitfull Germany," so escaping the Pope's judgment. Finally Bruno is seen at the court of the Emperor Charles in lines 1237-1253, accompanying Faustus, though he speaks no lines; and the last mention of him is on line 1253, after which he disappears from the play.

This summary of the essential action is necessary so that we note the changes from Foxe's Actes and Monuments. ${ }^{4}$ Oliver notes: "Rowley has reversed the order of the two popes, ${ }^{5}$ changed Victor's name to Bruno and

\footnotetext{
1 Doctor Faustus, ed. Roma Gill (New York, 1965): xiv.

2 All references to the text are to Greg's parallel text edition (Oxford, 1950).

3 Marlowe may have intended the contemporary Pope Sixtus V who was elected Pope 24 April, 1585. (Editor's note)

4 John Foxe, Acts and Monuments,7th ed. (London, 1632), I, 262-265.

5 Pope Alexander III (c. 1100 - 1181) and Pope Adrian IV (c. 1100 1159)
} 
given him the Emperor's lines to speak." ${ }^{6}$ But why change from Foxe's account the historical pope Alexander for the play pope Adrian, who, if he was the Adrian that Foxe was excoriating in the immediately preceding paragraphs, was Nicholas Breakspeare, pope from 1154-59, the only Englishman to be elected to the office? And why change the historical anti-pope Victor IV into Bruno, an apparently unhistorical name? Roma Gill concludes: "Historical fact has been confused, even violated." John Jump, a recent editor, notes: "Raymond and Bruno seem to have had no historical originals." ${ }^{8}$ And thus the matter now rests so far as contemporary scholarship is concerned. The fact that the change in names could not possibly proceed from anything except deliberate intention has curiously escaped from the spectrum of modern critical possibilities. No author using Foxe as his source, either in the first (1563) edition or any subsequent ones, could have "confused" the entirely plain meaning of the Foxe accounts. Additionally, the closeness of the verbal parallels makes it sufficiently clear, I think, that the play lines were written with more than a general recollection of Foxe's text. ${ }^{\text {? }}$

If the suggestion is entertained that the hiatus is intentional, the question remains, why? To answer this, it is essential to determine as precisely as possible the date of the composition of the scene. Greg's summary of the known evidence shows that Henslowe paid $f 4$ to Birde and Rowley on 22 November 1602 "for ther adicyones in doctor fostes" -- a substantial sum that implies considerable rewriting. ${ }^{10}$ Henslowe's records show that Faustus was performed 24 times between 2 October 1594 and 5 January 1597 before being discontinued; presumably the revival of the play with additions some five years after its demise followed closely on its rewriting. However, this renewed interest in Faustus was antedated by Thomas Bushell who on the 7 January 1601 "Entred for his copye vnder the handes of Mr Doctor/Barlowe, and the Wardens. A booke called the plaie of Doctor Faustus." 11 But no copy of any text has survived earlier than 1604, although Greg suggests we are free "to assume that Bushell followed up his entrance ... with an edition the same year." ${ }^{\prime 2}$

$6 \quad$ Leslie M. Oliver, "Rowley, Foxe and the Faustus Additions," Modern Language Notes, 60 (June 1945): 391-4.

$7 \quad$ Gill, p. xiv.

8 Doctor Faustus, ed. John Jump (Cambridge, Mass.,1962), note to p. 2.

9 Oliver gives most of the relevant comparisons, verbal and visual, e.g., the triple crown.

$\begin{array}{ll}10 & \text { Greg, p. 11 } \\ 11 & \text { Greg, p. 12 } \\ 12 & \text { Greg, p. 13 }\end{array}$


The text of 1604 comes to us in three extant editions - 1604, 1609, and 1611, known as the A-text for critical purposes. None of these editions has any hint of the anti-pope theme. The second substantial form of the play is the series of quartos (B-text) beginning with a 1616 edition printed for Iohn Wright and known in 6 editions, the last being of 1631. Greg concludes that much of the B-text was printed from A-3 (1611) - some 505 lines of the 2121. "All the rest of the B-text was set up from MS."13 There are some 679 lines of $\mathrm{B}$ which are peculiar to it, leaving some 937 lines "present in some form in A" also. ${ }^{14}$ Both sections of the B-text in which Bruno appears or is mentioned (B895-1022 and B1237-1253) are peculiar to B or are printed from MS and both sections are attributed by Greg to Rowley or whoever may be Marlowe's collaborator.

Actually, wary scholar that he is, Greg does not unequivocally commit himself to the idea of Rowley being the prime collaborator, but he leans that way: he cites Dugdale Sykes as evidence for an early association of Rowley with Marlowe. ${ }^{15} \mathrm{He}$ accepts as "quite possible" that Rowley was with Pembroke's men in 1592, ${ }^{16}$ and therefore that Rowley could have had a hand in the original composition.

As Greg's tables show, the degree of difference between A and B is substantial and I think, for the purposes of hypothesis, it is a plausible inference that Rowley's additions account for the Bruno scenes, ${ }^{17}$ the more so since the weight of Boas' and Greg's opinion on the style and syntax identifies the authorship of B895-1070 and B1237-1253 with Rowley. Most recent of all, in her Spring 1975 article in ELH, Constance Brown Kuriyama attacks Greg's designation of the B-text as the 'original' text, following up on Bower's (1973) article in SB, 26:1-18 which argued, against Greg's view, for A as the original text. ${ }^{18}$ Kuriyama points out a possibly significant change from the present to

\begin{tabular}{ll}
\hline 13 & Greg, p. 72 \\
14 & Greg, p. 73 \\
15 & H. Dugdale Sykes, "The Authorship of The Taming of the Shrew, The Fa-
\end{tabular}
mous Victories of Henry $V$ and the Additions to Marlowe's Faustus," The Shakespeare Association, 1920.

16 Greg, p.135

17 Both Fleay, Appendix A to Ward's edition of Faustus (Oxford, 1892), and Ulrici, "Christopher Marlowe and Shakespeare's Verhgatniss zu ihm," Jahrbuch der deutschen Shakespeare-Gesellschaft, i (1865), 64-65, assume "that the edition of 1604 contains the play as it was performed from 1597 onwards with additions by an earlier hand and the editions of 1616 the play as it was performed from 1602 onwards with the additions by Birde and S. Rowley.", notes Ward, pp. cvi-cvii.

18 Constance Brown Kuriyama, "Dr. Greg and Doctor Faustus: The Supposed Originality of the 1616 Text," English Literary History (Spring 1975): 171- 
the past tense in the 1616 text: "In A, the magicians refer to the gold that 'yearly stuffes old Phillips treasury'; in B the verb is changed to 'stuff'd' (A165:B154)... the reading of the 1616 text may also reflect the historical fact of Phillip's death in 1598". What she terms the "aesthetic dislocation of B reinforces our wellgrounded suspicions that Marlowe did not write the extra scenes of B, or B's versions of the comic scenes...." This article supports, then, the attribution of B895-1070 and B1237-1253 to Rowley, although it opposes Greg's hypothesis that Rowley might have worked on the original - i.e., A text--which is neither here nor there for my purposes. ${ }^{19}$ Inferentially, therefore, we have a date by which the Bruno episode was in existence - i.e., 22 November 1602, the date Henslowe paid Birde and Rowley. ${ }^{20}$

Next we should consider why Henslowe found it a good idea to revive Dr. Faustus after a lapse of five years - the last of the earlier performances being on the 5 January 1597. Did it reflect an expectation of a new public interest that Henslowe felt he could capitalise on? My hypothesis is that such a situation had arisen and that Henslowe took advantage of it. The suggestion is that the Bruno of the B-text is modelled upon Giordano Bruno, the Italian cosmologist, philosopher and unfrocked friar, burnt in Rome in 1600 .

The evidence for this is circumstantial and the suggestion is an old one that, so far as I can see, was first made by Friedrich Notter in $1847 .{ }^{21}$ The idea was apparently next handled by Ward, who commented: "It is hardly possible that there can be any allusion, as Notter suggests, to Giordano Bruno, who was burnt for heresy in Rome in 1600..."22 though Ward supplies no reason why this is not possible. Lastly, Greg in his edition records Ward's rejection of the idea "as improbable." 23 Yet, since Ward's edition, a considerable amount of historical fact has been unearthed that provides reason to revise this estimate; facts that tend to link Marlowe and Bruno through associations of interests and shared friends -notably Thomas Watson, and I should like to summarise parts of them.

197.

19 Editor's note: Thomas Pettitt has documented that the A-text derives from the B-text, where they have material in common. "Marlowe's Texts and Oral Transmission: Towards the Zielform," Comparative Drama (2006 vol 39), 2: 213-42.

20 Editor's note: For an argument against Rowley's authorship based on stylistic analysis, see Roy Eriksen, The Forme of Faustus Fortunes. A Study of the Tragedie of Doctor Faustus (1616), (Atlantic Highlands N.J.: Humanities Press, 1987), 220-221.

21 In Die Sage vom Faust, ed. Jakob Scheible (Stuttgart and Leipzig, 1847), V, pp. 1017 following. See also item a1044 in Tannenbaum's Marlowe Bibliography.

22 Ward, Notes to the 'Dramatis Personae.

23 Greg, p. 352 
Firstly, there is the fact of Bruno's stay in England from 1583-5. Sir Henry Cobham, English ambassador in Paris, wrote to Sir Francis Walsingham on 28 March 1583: "Doctor Jordano Bruno Nolano, a professor in philosophy, intends to pass into England, whose religion I cannot commend." ${ }^{24}$ Bruno stayed in London, principally at the house of the French ambassador, Michel de Castelnau, and left with him in October 1585 when he returned to France. ${ }^{25}$ During this short period of time Bruno had had printed in England six works of philosophical speculations (STC 3934-3940) and had gained access to an astonishingly wide circle of friends and fellow-students of mnemonics and cosmology: these are discussed in Singer. Of these, the principal members of interest for our purposes are Thomas Watson and John Florio.

Thomas Watson visited Paris in 1581 and his aptitude in Latin attracted the attention of Stephen Broelmann of Cologne, jurist and poet, who advised him to publish his Latin verses. At the same time he appears to have met Sir Francis Walsingham there on a mission in the summer of $1581 .{ }^{26}$ Bruno arrived in Paris sometime in the same year and Watson may have met him there. ${ }^{27}$ Watson's interest and proficiency in Italian was demonstrated in 1582 by his Hekatompathia: including, by his own account, eight renderings from Petrarch, twelve from Serafino dell'Aquila; four from Ronsard and many from classical authors used as sources. In 1585 he published Amyntas - an imitation of Tasso in Latin hexameters. In 1590 Sir Francis Walsingham died and Watson under the pen name Meliboeus lamented his death in a Latin elegy (STC 25120-Englished edition STC 25121). The Dedication is to Sir Thomas Walsingham, Sir Francis's cousin - with whom Marlowe was staying when arrested by the Privy Council on 18 May $1593 .^{28}$

The interest of the title page is this: that the name Meliboeus (for Watson) occurs in one of the Dialogues that make up Florio's Second Fruites (1591), as does Bruno under his more usual title of "Nolano" in the first

24 Calendar of State Papers, Foreign, Jan-June 1583, p. 214. Quoted by Frances A. Yates, Giordano Bruno and the Hermetic Tradition (Chicago, London, and Toronto, 1964), p. 204. The Walsingham addressed is wrongly identified as Thomas Walsingham in the index of Dorothea W. Singer's Giordano Bruno: His Life and Thought (New York, 1950).

25 Frances A. Yates, p. 292. My facts on Bruno are drawn generally from Singer and Yates: their references as far as possible I have checked through Bruno's collected works, Opere di Giordano Bruno e di Tommaso Campanella, a cura di Augusto Guzzo e di Romano Amerio (Milano: Napoli, n.d.).

26 DNB. See Bruno's reference to "l'eccellentissimo signor Francesco

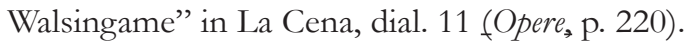

27 Singer, p. 40

28 J.L. Hotson, The Death of Christopher Marlowe (London, 1925), established the details of Marlowe's last days. 
Dialogue. Other historical characters occur under such pen names in the same work. Two other points of significance also emerge: the phrase on the title-page "divae Elizabethae" reminds us that Bruno had so referred to Elizabeth as "diva Elizabetta" in his De la causa, principio et uno (1584) and had to retract it in front of the Venetian inquisitors later. ${ }^{29}$ Secondly, the Robert Robinson of the 1590 Meliboeus is the same man who, it has lately been established, was the printer of the earliest known edition $\left(8^{\circ}, 1594\right)$ of Marlowe's Edward II. ${ }^{30}$ This suggests that Watson and Marlowe may have had common business acquaintances. To complete the evidence of Marlowe's friendship with Watson is easy; it is presented in Mark Eccles' Christopher Marlowe in London (Harvard, 1934) and a little comment is needed, Watson killed a man, William Bradley on 18 September 1589 in Hog Lane, apparently in self-defence, when he intervened in a fight between Marlowe and Bradley. This dramatic event also led Eccles to conclude that 'C.M.', the initials of the writer of the dedication of Watson's Amintae Gaudia_(SR, 10 Nov. 1592), were those of Marlowe--an ascription now accepted. The second person whom Bruno was familiar with was John Florio. "John Florio is one of the fixed points in Bruno's career," notes Singer. He had joined Castelnau's household in 1582. ${ }^{31}$ Bruno and Florio clearly were in daily contact for long periods: but there is actual evidence of a closer association than the casual. Two instances will serve here. In 1591 Florio published his Second Frvtes in which some 6000 proverbs, aphorisms and common sayings are incorporated as part of an English-Italian language manual in dialogue form. The first chapter presents the characters Nolano and Torquato set in a domestic scene: Nolano is of course Bruno. In the fourth chapter, Florio introduces us to a new group, including Nundinio and Melibeo, "between whome, there fall many pleasant discourses, concerning meate \& repast." Meliboeus we recall from Watson's work referred to above and produced a year earlier--and there is little doubt that Watson is referred to here. Writing your friends into a didactic work is a pleasant custom, I think.

A second instance of Florio's growing interest in Bruno may be suggested by the following set of circumstances: (i) Florio's World of Wordes (1598) lists 72 works "for the accomplishing of this Dictionarie, and out of which it is collected." : included are 15 works by Aretino; not one by Bruno. (ii) In 1611, Florio expanded his dictionary (from c. 46,000 to some 74,000 words) in a new edition called Queen Anna's New World of Wordes, and lists 249 works

29 Quoted by Yates, p. 288 from V. Spampanato, Documenti della vita di Giordano Bruno (Florence, 1933), pp. 121-122: "And I know that I erred in praising this lady, she being a heretic, and above all in attributing to her the name of 'diva'."'(Yates' trans.).

30 Robert F. Welsh, "The Printer of the 1594 Octavo of Marlowe's Edward II," Studies in Bibliography, 17 (1964): 197-198.

31 Singer, p. 29 
consulted: 5 are "del Nolano." 32 It would be curious that Florio does not use Bruno in the 1598 edition, but does in the 1611 one, when Bruno was even more distanced in his memory - unless the name has acquired fresh significance and interest. Florio's use of him in Second Frvtes, 6 years after he had left England, suggests the association was still alive sufficiently in his memory or those of his circle to make his incorporation in the first chapter evocative. By 1598 Bruno had been largely forgotten perhaps in England, or the knowledge that he had been in the hands of the Inquisition since 23 May 1592 made reference to him possibly prejudicial to his hopes of release. But after 1600 the fact of his burning must well have revived his name - hence possibly the listing of his works, all 5 of which were published during his stay in England.

These brief summaries suggest enough of, the nature of the association between Watson, Bruno and Florio, and the general conclusion that I would draw is that through Watson, Marlowe can be considered as having access to the thought, the work and indeed the personal quality of Bruno; and that in company with Watson, Marlowe was a member of a circle that touched, sometimes became concentric with, others that included Florio, Kyd, Hariot and Royden, to say nothing of those members of the so-called 'School of Night' with whom his name is frequently linked. The evidence above makes it clear that Marlowe shared some of the interests of his associates - the sort of speculative interest in the power of the mind, the nature of the infinite, the cosmological processes, which finds particular expression in his tragic drama. Had not the Faustbook of 1592 (see note 44), englished by P.F. Gent., arrived as a ready source for Marlowe, it is quite possible that he could have turned to the theme on the strength of his knowledge of Bruno.

The question that must be faced, then, is this: Marlowe being dead in 1593, who could have written in the Bruno scenes, necessarily composed in the form in which they appear in the B-text, after 1600, and why? The answer has been implicit in what has gone before, that Bruno was an interest of Marlowe's and that the adoption of the Faust theme is in part to be ascribed to it; and that the reason for incorporating the Bruno scenes in the B-text was that Bruno had acquired public value in England since his burning.

This conjecture would receive stronger support if it could be shown that there was any sort of private or public reaction in England to Bruno's burning. Thomas Bushell's 7 January 1601 entry in Stationers' Register for Dr. Faustus was mentioned earlier--about 10 months after Bruno's burning.

Florio's listing of Bruno as a source for his 1611 dictionary has already been mentioned. Henslowe's revival of Faustus in the altered form could so be interpreted.

32 Longworth Chambrun, Giovanni Florio (Paris, 1921), p. 78 estimates the word totals: the works listed are supplied as Appendices to her volume; the count is mine. 
I have not been able to find any references that show an English awareness of Bruno's burning. The letter of Gaspar Schopp to Conrad Ritterhausen relating the burning (which he witnessed) and written on the same day, is well known, and from Germany the news would not be long in making its way to England, it would at least have arrived before the end of the year (1600), a period of ten months since the burning. ${ }^{33}$ In 1607 Kepler wrote to Johann Brengger, a doctor, and they discussed Bruno's death. ${ }^{34}$

To sum up, Notter's suggestion that Bruno in the 1616 text is Giordano Bruno appears to be more possible in the light of modern scholarship's revelation of new fact than seemed likely at the time it was made. ${ }^{35}$ The fairly strong identification of Rowley as the author of much of the additional material in the B-text, on the basis of association, stylistic peculiarities and his use of Foxe, coupled with a possible coterie appeal for the "writing in" of Bruno, makes the conjecture feasible. ${ }^{36}$ If Rowley was an original collaborator, he may have had private reasons for adding this indirect memorial to Marlowe's memory and have been able to use them to take advantage of public sentiment that was strongly anti-Catholic still and saw in Bruno's martyrdom a further confirmation of Papal savagery. ${ }^{37}$

\section{Nicholas Ranson \\ University of Akron}

33 See V. Salvestrini, Bibliografia di Giordano Bruno, 2nd ed. (Firenze, 1958), items no. 10, 290 and 325. The letter was first published more or less complete, by B.G. Struve in 1707 at Jena from the original letter in the Breslau Communal Library. [Salvestrini No. 328]

34 Quoted Singer, p. 190, n. 21.

35 Editor's note: For further support of the identification of the play's Bruno with Giordano Bruno, see Roy Eriksen, "Giordano Bruno and Marlowe's Doctor Faustus (B)," Notes \& Queries, 32.4 (December, 1985): 463-65, and The Forme of Faustus Fortunes, 1987: 59-102.

36 Greg, pp. 133-136 lists the tricks of style characteristic of Rowley, which, though not confined to him, are certainly consistent with his style in When You See Me You Know Me--especially the use of latinate adjectives ending in -al. There are examples in the B-text in lines 172, 898, 912, 953, 992, 1004, 1266.

37 I have throughout adopted the general views of Greg regarding dating: the fact that C.L. Barber, Robert Ornstein and P.H. Kocher have expressed a preference for the 1604 text as more Marlovian is a preference for style, content and unity of theme that leaves the main conjecture of this paper unaffected. Even if H. Jenkins is right [Modern Language Review, 46 (1951)] in his review of Greg that the arguments for Faustus being written before 1590 are as strong as those for after 1592, the idea of Rowley as an early collaborator would be marginally affected at most, and the Bruno hypothesis not at all. 